\title{
OM X FM MIGRATION REFLEXES
}

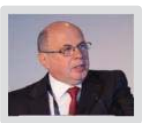

Moderator: Jose Eduardo Marti Cappia

Director - EMC / SET

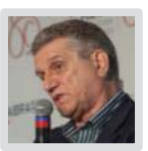

Canalização FM - Revisão - Redução De Classes

Speaker: André Cintra

Engineer - ALUC / Abert / SET

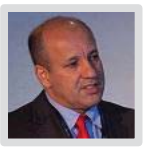

Equipamentos na Migração - Faixa Convencional e Faixa Estendida.

Speaker: José de Mauro Ávila

Technical Director - Mega Communication System / SET

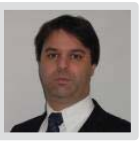

Receptores na Faixa Estendida FM, Alternativas de Recepção Veicular e Smartphones.

Speaker: Cauê Franzon

Technical and Operations Manager - RBS Rádios / SET

Revisão de Norma Técnica FM - Realidade Atual

Speaker: Cláudio Lorini

DIRETOR / Lorini Engenharia Ltda e LoriService Radiodifusão e

Telecomunicações 


\section{9h00 - 11h00 | 31/08/2016 Wednesday | Room 12}

\section{Radio}

\section{OM X FM MIGRATION REFLEXES}

\section{Moderator: Jose Eduardo Marti Cappia}

Director - EMC / SET

55 migrants stations complete the qualification phase with the MC and signed grant adaptation contract with the union.

Understanding deadlines and stages of conventional FM band, their challenges and technical validation. Extended FM range, 76-88 MHz, reserved for more than 350 migrants. Receptors and the experience of Jovem Pan - São Paulo - 84.7 MHz. In the topic update on Migration, "What the broadcaster should know" it is dedicated to share experiences and questions concerning the process, and legal details such as contracts, terms and stages to be overcome in channeling effectiveness, as well as the technical aspects of antennas and transmitters.

Equipment transmitters and FM receivers. Changes in the technical regulation welcoming the migration mainly regarding the extended range $76-88 \mathrm{MHz}$.

- Canalização FM - Revisão - Redução De Classes

Speaker: André Cintra

Engenheiro - ALUC / Abert / SET

Apresentará o resultado da revisão de canalização $\mathrm{FM}$, destinada a acomodar o maior número possível de emissoras na faixa FM convencional, de 88 a $108 \mathrm{MHz}$, com a anuência de redução de classes pelas emissoras. Apresentará a situação da canalização das Zonas de Coordenação das faixas de fronteira, bem como critérios técnicos que facilitam as viabilizações.

- Equipamentos na Migração - Faixa Convencional e Faixa Estendida Speaker: José de Mauro Ávila Diretor técnico / Mega Sistema de Comunicação / SET

Com foco nos equipamentos de transmissão e monitoração para as emissoras FMs da faixa convencional e estendida de 76 a $108 \mathrm{MHz}$. Citará as empresas que estão aptas a fornecer equipamentos para a faixa estendida e que aguardam a mudança de norma de certificação de equipamentos pela Anatel.

- Receptores na Faixa Estendida FM, Alternativas de Recepção Veicular e

\section{Smartphones}

Speaker: Cauê Franzon

Gerente Técnico e Operacional / RBS Rádios / SET

Abordará os temas relacionados a penetração do rádio no mercado brasileiro, os dispositivos para recepção na faixa estendida no FM bem como a disponibilidade de equipamentos para transmissão. Trará uma atualização de como mercado produtor de receptores é sensibilizado na produção de equipamentos de 76 a $108 \mathrm{MHz}$.

\section{- Revisão De Norma Técnica Fm - Realidade Atual}

\section{Speaker: Cláudio Lorini}

DIRETOR / Lorini Engenharia Ltda e LoriService Radiodifusão e Telecomunicações

Especialista no setor de radiodifusão, abordará técnica e juridicamente tópicos que merecem ser revistos no Regulamento Técnico do serviço de radiodifusão sonora em FM, em vista do processo migratório AM \& FM e sua atualização com a faixa estendida. Apresentara conceitos para relaxamento de relações de proteção da canalização. 


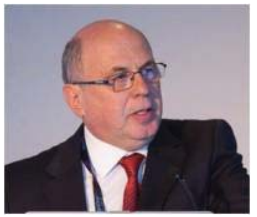

\section{JOSE EDUARDO MARTI CAPPIA}

\section{Director - EMC/SET}

He graduated in 1979 from the University of Mogi das Cruzes. He is an Electrical Engineer qualified in Electronics and Power Engineering $\mathrm{He}$ is a director at EMC - SOLUÇÃO EM TELECOMUNICAÇÕES, a telecommunications solutions company. Since 1991, EMC - a company famed for carrying out HD radio tests at the UFMG, Belo Horizonte, in partnership with the Ministry of Communications, at Cordeirópolis (SP) and DRM in Belo Horizonte, with the focus on low-power stations. Assessment and defense of his thesis on the coexistence of digital broadcasters on the first underlying FM channels. Implementation in 2014 of the scientific and experimental testing station in eFM - 84,7 MHz -Jovem Pan - São Paulo, with the support of the AESP, where he has been technical leader since 2011, having renewed his engagement up to 2016. He actively participates in evaluating the reception on extended range smartphones. Deputy Director for Radio at SET since 2011. Author of papers on spectral efficiency, with the support of

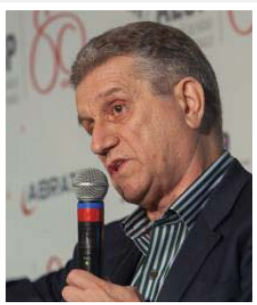
measurements from diagrams of irradiant antennas and their effective gains.

\section{ANDRÉ CINTRA}

\section{Engineer - ALUC / Abert / SET}

Communications Engineer - Specialized consultant in broadcasting channel planning, currently working on the FM Channelization for the ABERT, to accommodate migrating channels. Undertook for SET the work for accommodating the TV channelization of UHF channels 14 to 51 .

\section{JOSÉ MAURO DE ÁVILA}

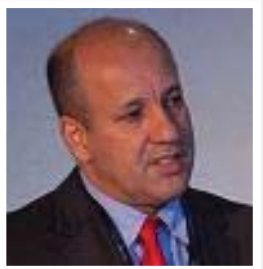

Technical Director - Mega Communication System / SET

Electrical Engineer and Occupational Safety Engineer from Paulista University in 2008. Qualified as an electronics technician from the Moura Lacerda institution 1982.

A regular participant at NAB - Broadcast Engineering Conference since 1992. Performs at different seminars of Brazilian entities engaged in the sector, such as AESP, SET and ABERT. Broadcast Electronics - Product Training Seminar - Audio Vault Administrator/VAR Sales 1999/2000/2002/2006/2013. Harris Corporation - Emphasis: Harris HT 35FM transmitter - 1991. $\mathrm{He}$ is also currently deputy Leader of the AESP Technical Committee and continues to work in technical support for Broadcast Electronics in Brazil in the case of automation systems.

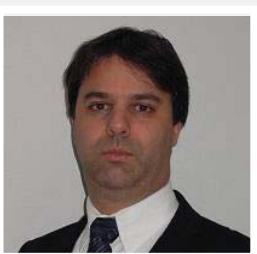

\section{CAUE FRANZON}

Technical and Operations Manager - RBS Rádios / SET

Academic Background: Mastering in Production Engineering at the Federal University of Rio Grande do Sul - UFRGS; an MBA in Project Management, FGV - 2012; Electrical Engineering Emphasis on Control and Automation - UNISINOS - 2004; Technical Course in Electronics Liberato Salzano Vieira da Cunha Foundation - 1996

Professional activities:Infrastructure Manager - RBSTV since 2012; Technical Manager - RBS Radios since 2009; Coordinator of the television products and solutions research group - RBS TV, from 2006 to 2009; audio and video maintenance technician - RBS TV, from 1997 to 2006

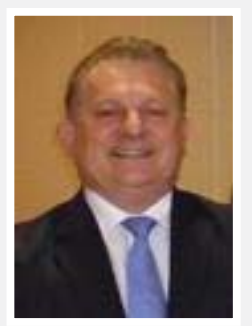

\section{CLÁUDIO LORINI}

Director - Lorini Engenharia Ltda e LoriService Radiodifusão e Telecomunicações.

An engineering graduate from the Pontifical Catholic University of Rio Grande do Sul - PUC, and a specialization in Telecommunications and Information Networks, from PUC Porto Alegre; Law Degree from the Department of Legal and Social Sciences - School of Law, Porto Alegre/RS of the Pontifical Catholic University of Rio Grande do Sul - PUC, with specialization in Telecommunications Law.

Rádio e TV Gaúcha - Porto Alegre/RS, Department of Technical Projects and Field Measurements for Rio Grande do Sul/ Santa Catarina/Brasília. Worked in the Dept. of Engineering and Manufacturing Industry for energy generation for three years at Stemac Geradores.

He has worked for Lorini Engenharia Ltda./Loriservice - Radiodifusão e Telecomunicações since its foundation in 1981 - Porto Alegre/RS, servicing broadcasters across a range of aspects, from technical to legal, during implementation and operation.

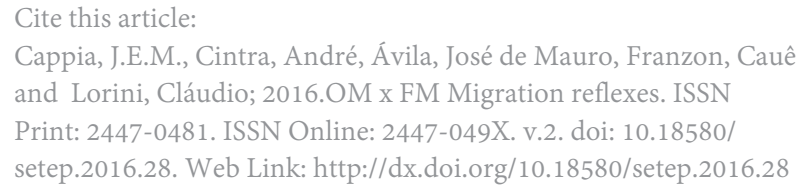

